\title{
Discourse of Love as Discourse of War and Battle: from Mythology to Philosophy
}

\author{
Vitali Turenko \\ Ph.D., Junior Research Fellow, Taras Shevchenko National University of Kyiv \\ (Kyiv, Ukraine) \\ E-mail: vitali_turenko@ukr.net \\ https://orcid.org/0000-0003-0572-9119
}

The paper shows the transformation of the idea of the unity of love and war from the mythology to philosophical discourse. Based on a number of theoretical and empirical arguments, the author hypothesizes that the "polemical" (warlike) Eros's image as archer with arrows has its foundation in Middle Eastern (Sumerian-Acadian, Semitic) mythology, which saw not the opposition of love and war, and a close relationship of these phenomena in the image of Ishtar (Inanna, Astarte). It emphazises that the philosophical aspect of understanding this issue is associated with two phenomena - power and gift. Accordingly, it is within the framework of the discourse of love that the "ravishing" takes place, the effect of which is explained by the fact that having subjugated the object of love, the subject himself obeys him. At the same time, in the context of the gift, there is an "agon", that is, a competition between those in love regarding the exchange of gifts and pleasures. It is shown that in today's Ukrainian realities this problem may also be relevant in the context of the current war in the East of the country.

Keywords: love, love discourse, war, battle, gift, Eros

Received: March 13, 2019; accepted: April 20, 2019

Ukrainian Policymaker, Volume 4, 2019: 62-68.

https://doi.org/10.29202/up/4/9

\section{Introduction}

At first glance, love and war seems that two incompatible phenomena. War brings death, suffering, sorrow, but love - joy, happiness and pleasure. However, the history of culture suggests that in reality not all is so one-sided with these phenomena. Accordingly, in essence love and war are quite interconnected.

The scientific work of Roland Barthes [Barthes, 2001], Nina Braginskaya [Braginskaya, 2011], Anton-Hermann Chruost [Chruost, 1980], Deni de Rougemont [Rougemont, 2004], Andrey Yarovoy [Yarovoy, 2017] and others became the theoretical and methodological basis of this study. Also, one can mention the fundamental work of Tom Digby [Digby, 2014], on how love and war influence social transformations, but it is directly related to the culture of

(C) Turenko, Vitali, 2019 
postmodernism. Therefore, in existing studies, we cannot find a comprehensive philosophical view of the studied issue.

Accordingly, the purpose of this article is the conceptualization of the idea of polemical and agonistic of nature discourse of love in the philosophical context.

\section{Mythologycal aspect of interconnected of love and war}

The origins of the understanding of the interconnected of love and war dates back to ancient times. It is in ancient mythology that through the image of Eros we find the key to the polemical and agonal nature of the love discourse. Of course, it can be noted that there are about two dozen versions of the origin of Eros from Homer to Neoplatonic School, but the image of the boy with the arbaleth and arrows has become the most popular in the world culture.

The version of the origin of Eros from the Olympic gods of Ares and Aphrodite, which prevails in modern reference books, belongs directly to Simonides Keos (fr.24 (70)). However, as Nina Braginskaya observes, "we do not go from speculative mythology. If we look at the War-Ares and Love-Aphrodite in the cosmogonic context, then this couple of parents of Eros will certainly remind us of $\Phi \uparrow \lambda i \alpha_{\alpha}$ and Nعíkos Empedocles, rather than the lovers of the "frivolous" scene in the song of Demodok" [Braginskaya, 2011: 58].

In this context, it will be appropriate to recall the article by Western scholar Anton-Hermann Chroust on the influence of Zoroastrianism on the teachings of Plato and Aristotle, in which he puts a few pages in this context and early Greek philosophy. According to him, the well-known

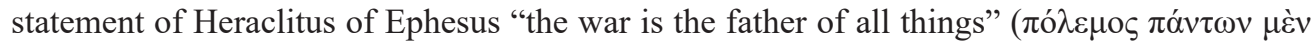
$\pi \alpha \tau \eta \dot{~ \varepsilon ̇ \sigma \tau \iota) ~[22 ~ B 53 ~ D K] ~ r e l a t e s ~ t o ~ t h e ~ e t e r n a l ~ s t r u g g l e ~ b e t w e e n ~ A h u r a m a z d a ~ a n d ~ A h r i m a n, ~ a s ~}$ well as Empedocles's statement that Love and the Hate are two basic principles or factors, who rule the universe, dominant in turn. These two examples, which can be greatly expanded, must really prove that some early Greek philosophers were familiar with the teachings of Zoroaster to one degree or another" [Chroust, 1980: 354-355]. Thus, we can say of the Eastern, but rather the Middle Eastern influences on the formation of dualistic cosmogony of early Greek philosophers.

Since love and war are closely linked in pre-Socratic philosophy and have Middle Eastern influence, we can put forward the hypothesis that the ancient goddess Inanna (ancient Acadian Ishtar, Semitic Astarte) appears at the base of this.

In support of this hypothesis, there are two factors:

1. Western scholars Jeremy Black and Anthony Green emphasize that her iconography is associated with wings and weapons [Black \& Green, 2004: 108-109].

2. Valeria Afanasyeva and Igor Dyakonov note that "the theonym "Ishtar" comes from Astar, which in the pre-Semitic period meant the planet Venus in one of two aspects, transmitted, respectively, as Astar (morning star, male character) and Astarte (evening star, female character). In West-Semitic and South-Arabian mythology, this division has survived; in the East-Semitic environment (the ancestors of Acadians), both aspects merged into a single deity, retained the characteristics of both sexes: on the one hand Ishtar - the deity of war, on the other - sex and childbirth; while the word Astar in the Eastern Semites meant the goddess in general" [Afanasyeva \& Dyakonov, 1991: 595]. 
The Lexicon iconographicum mythologiae classicae (LIMC), which contains images of Eros, Amur, and Cupid of exclusively winged infants, adolescents and boys, can also serve as proof of our hypothesis. Eros as Apteros occurs in late Roman art, when the excess of other attributes makes wings already excessive. On the bow, we will only say that a young man with a bow as a companion of Ashtar was honored in Cyprus and from the two inscriptions, was considered there Apollo. This young man, as the companion Qetesh in Egypt, is named after Resheph. The Apollo on Crete absorbed the features of Resheph, and the bow remained with him, but he himself did not stay with Astarte-Aphrodite. Her companion became another god with bow. Science has long been accustomed to seeing syncretism in the period of Hellenism, and in recent decades it has become accustomed to the fact that the archaic Greek and early classics are permeated with eastern influences [Lexicon, 1986: 1050].

As we see, Eros appears to be a warrior in the context of love, he his gun both gives and punish people. Whoever seeks to love - he protects, and whoever resorts to run away from love - is doomed to suffering and trials. Eros - the personification of a warrior of love, because being a companion of his mother Aphrodite he helps her in her affairs. However, because he owns a weapon, he feels courage and impunity, which leads to various kinds of "love games."

However, this militancy of Eros in philosophy implicitly appears as a manifestation of courage. In particular, we encounter this in Phaedr's speech at Plato's "Symposium," where he says the following: "For what lover would not choose rather to be seen by all mankind than by his beloved, either when abandoning his post or throwing away his arms? He would be ready to die a thousand deaths rather than endure this. Or who would desert his beloved or fail him in the hour of danger? The veriest coward would become an inspired hero, equal to the bravest, at such a time; Love would inspire him. That courage which, as Homer says, the god breathes into the souls of some heroes, Love of his own nature infuses into the lover" [Symp, 179a-b]. The same attribute of Eros we can see in the speech of Diotima [See: Symp, 203d-204a].

Due of this attribute of Eros, the person who love is given the opportunity to do wonderful things, and, consequently, to be a hero. Love, in the opinion of Phaedrus, is stronger than a thousand deaths. Parental and friendly feelings are not so wonderful and impressive. So, only the love of a man/woman to an individual of the opposite sex can help a person make heroic deeds. That is why, when Phaedrus represents the first panegyric of love at the "Symposium", emphasizes the attention of listeners on such a gift of love as the willingness to go to any sacrifice for the sake of his beloved person. In addition, Phaedrus notes that nobody will die for you, but only one who sincerely loves [see: Symp, 179b].

This courage and inspiration is connected not only with military implements, but also with the fact that Eros had wings. However, "the presence of powerful flying muscles and keel, to which they are attached, would greatly increase the size of the chest and change its shape. However, in the sculptural and pictorial images of winged gods (including Eros - V.T.), no signs of deformation of the chest are not visible. This can be explained by the fact that they (not only in the form of Eros- V.T.) wings had not so much a functional meaning as a symbolic one, since the gods could fly without their help" [Ivanova-Kazas, 2004: 97].

Consequently, the image of Eros (Amur) in ancient culture is a direct mythological embodiment of the unity of the discourse of love and the discourse of war. The basis of this ancient understanding is the Sumerian-Acadian mythology, which saw no opposition to love and war, but a close affinity of these phenomena in the form of Ishtar (Inanna, Astarte). By 
giving or subtracting love to people or gods, Eros carries out this through military weapons (bow and arrows). Thus, this image becomes basis the groundwork for the further development of an explication of polemical and agonistic nature of love.

\section{Love as "ravishment" and "agony of gift": philosophical aspects of understanding}

First of all, philosophical context of the unity of love and war, thinkers see in the phenomenon of power, in the act of ravishment, that is, such an act that combines both power and capture of the subject of love. Roland Barthes observing that this conception is outdated, notes that it is undergoing a radical transformation, writes: "However, there is an odd turnabout here: in the ancient myth, the ravisher is active, he wants to seize his prey, he is the subject of the rape (of which the object is a Woman, as we know, invariably passive); in the modern myth (that of love-as-passion), the contrary is the case: the ravisher wants nothing, does nothing; he is motionless (as any image), and it is the ravished object who is the real subject of the rape; the object of capture becomes the subject of love; and the subject of the conquest moves into the class of loved object. (There nonetheless remains a public vestige of the archaic model: the lover- the one who has been ravished — is always implicitly feminized.)" [Barthes, 2001: 188].

However, in our opinion, the dialectic of this transformation is removed in the next "subjugating someone, the subject submits himself". As in this context, Emmanuel Levinas observes appropriately: "To love means to endure the Other, to be a helper in his weakness. Love means being-for-another. True love is the discovery of good: it does not require from whom we love the impossible, but in the direction of its weakness, gives it to itself, that is, in the end awakens the love in it. Loving her, I do not expect her to subordinate, confirm the power of my "Self", giving to me the secrets of her tenderness. Loving her truly, I rejoice in her joy, I enjoy her pleasures, love her love that has turned to me" [Malakhov, 2008: 366].

Thus, ravishment, which accompanies the discourse of love, according to Roland Barthes, "is a hypnosis: I am fascinated by an image: at first shaken, electrified, stunned, "paralyzed" as Menon was by Socrates, the model of loved objects, of captivating images, or again converted by an apparition, nothing distinguishing the path of enamoration from the road to Damascus; subsequently ensnared, held fast, immobilized, nose stuck to the image (the mirror). In that moment when the other's image comes to ravish me for the first time, I am nothing more than the Jesuit Athanasius Kirchner's wonderful Hen: feet tied, the hen Athanasius Kirchner went to sleep with her eyes fixed on the chalk line, which was traced not far from her beak; when she was untied, she remained motionless, fascinated, "submitting to her vanquisher", as the Jesuit says (1646); yet, to waken her from her enchantment, to break off the violence of her Imagerepertoire (vehemens animalis imaginatio), it was enough to tap her on the wing; she shook herself and began pecking in the dust again" [Barthes, 2001: 189-190].

Such an affection, ravishment for the subject of love is due to the fact that the subject understands that the Other is a miracle, something wonderful in this world, which is not subject to any classification, "atopic" (Roland Barthes). Such a confusion of the miraculous nature of love (and hence the object of love) is that it appears in our lives by chance; it is not predefined. It seems that here are 20-25 years of our life - and time to think about personal life, but no matter how we plan, love comes when she wants it. We can go to a nightclub or in some place a mass gathering of people, to go there every month, but so nobody can meet. 
And we can ride the last train of the subway for half past night...and except me in the entire train is also one person (the opposite sex), each of us thinks about yours, but... suddenly our eyes crossed and we suddenly smiled at each other. As a result, the guy took the girl's address/ phone, and if you take the context of the $21^{\text {st }}$ century, find out if it is in social networks, etc. ... so their love story was born.

At the same time, lover's ravishment is not immediately, but gradually, it contains primarily local content, and then it is total. Roland Barthes in regard to this says the following: "In the animal world, the release switch of the sexual mechanism is not a specific individual but only a form, a bright-coloured fetish (which is how the Image-repertoire starts up). In the fascinating image, what impresses me (like a sensitized paper) is not the accumulation of its details but this or that inflection. What suddenly manages to touch me (ravish me) in the other is the voice, the line of the shoulders, the slenderness of the silhouette, the warmth of the hand, the curve of a smile, etc. Whereupon, what does the aesthetic of the image matter? Something accommodates itself exactly to my desire (about which I know nothing); I shall therefore make no concessions to style... The feature which touches me refers to a fragment of behaviour, to the fugitive moment of an attitude, a posture, in short to a scheme ( $\sigma \chi \eta \mu \alpha$, schema, is the body in movement, in situation, in life)" [Barthes, 2001: 190-191].

Lover's ravishment cannot occur totally. It is carried out gradually, measured. Usually, unlike passion and attraction, love does not like "speed". She does not pay attention to what everyone is looking at, but to the fact that others do not seem to be so important. It is in this and her special power, depth and height. Love does not begin with a great one, it starts from a small, from the same love to some kind of detail of the human body, human behavior, character or temperament. Only gradually, knowing the object of love, it deeper and more fully begins to love.

Roland Barthes describes this: "When Werther "discovers" Charlotte (when the curtain parts and the scene appears), Charlotte is cutting bread-and-butter. What Ranold falls in love with is a woman walking (Gradiva: the one who comes toward him), and furthermore glimpsed within the frame of a bas-relief" [Barthes, 2001: 193]. Accordingly, it is already in the feeling of love that a person loves totally the object of love; it covers it completely, and does not give it up, which is supposedly beautiful, but not so much. It is this phenomenology of feeling that reflects the direct opposite to the commonly used social stereotype that "men love their eyes, and women are ears." In fact, they are completely and completely loved both internally and externally. Love cannot be "half," or "a quarter," it loves the whole person with all its weaknesses and strengths.

However, the question arises as to why the agonality in the discourse of love manifests itself. As we know, the agon (from ancient Greek $\dot{\alpha} \gamma \omega$ v) meant a struggle or competition in ancient Greeks and Romans. Accordingly, in the discourse of love there is also a kind of competition, namely the exchange of gifts. Barthes writes about this following: "The amorous gift is sought out, selected, and purchased in the greatest excitement-the kind of excitement which seems to be of the order of orgasm. Strenuously I calculate whether this object will give pleasure, whether it will disappoint, or whether, on the contrary, seeming too "important," it will in and of itself betray the delirium or the snare in which I am caught. The amorous gift is a solemn one; swept away by the devouring metonymy, which governs the life of the imagination, I transfer myself inside it altogether. By this object, I give you my All” [Barthes, 2001: 75]. 
At the same time, the gift is a request for reciprocity, not necessarily by things and objects, but simply for some kind of answer. Because of this, there is a constant donation to each other of a certain kind of enjoyment, which is similar to a kind of competition (agon), who will give more. However, unlike sports or games, in the discourse of love there are no losers, the two are loving and are the winners, that is, those who feel the true feelings of love for each other.

\section{Ukrainian reality in the context of connection of love and war}

In today's Ukrainian realities this philosophical problem may also be relevant in the context of the current war in the east of the country. Of course, we are talking about the fact that love and war are interconnected in an existential plane. It's not so much about love as war, but about the meaning of love, the discourse of love during the war. As we know this kind of limit situation as a war, especially shows the sincerity of feelings, the importance of man for the Other, and other moments.

Correspondingly, during the years of the current war in the east of Ukraine, many plots were shot, many books written about those or other love stories that often capture the spirit. This shows that love during the war is not "a loud phrase", but the appearance (or disappearance) of it emphasizes the importance of this phenomenon in the life of any person. However, it is not only about marital love, but also in other forms - as the relationship between parents and children, brothers and sisters, in general between people. Not without reason, after all, Plato wrote that "And if there were only some way of contriving that a state or an army should be made up of lovers and their loves, they would be the very best governors of their own city, abstaining from all dishonour, and emulating one another in honour; and when fighting at each other's side, although a mere handful, they would overcome the world" [Symp, 179a].

\section{Conclusions}

Thus, after analyzing of understanding the discourse of love as a discourse of battle and war, we can draw the following conclusions:

1. The basis of this concept lies in ancient mythologies. According to my opinion, the famous image of Eros (Amur) as an archer with arrows through the figure of the goddess Ishtar, who was patroness of both love and war reaches its foundation in ancient Shumerian mythology.

2. The philosophical vector of this issue is manifested in two vectors: the discourse of love as «ravishment», that is, the concept, which denotes both the act of conquest and the process of ravishment by the beloved person. At the same time, within the discourse of love there is also the "agony of gift», which is marked by a kind of competition between the loving ones regarding the exchange of gifts between them.

3. Due the current war in the East of Ukraine, we can note that our issue should be connected in an existential plane. At the same time, in contrast to the purely philosophical reflection, within the framework of the socio-philosophical and ethical discourses, here we can talk not only about marital love, but also in other forms of love - between parents and children, brothers and sisters, friends, etc. 


\section{매] References}

Afanasyeva, Valeria and Igor Dyakonov. Ishtar, Myths of the peoples of the world, Encyclopedia in 2 v. V.1. (A-K). Moscow: Soviet Encyclopedia, 1991.

Barthes, Roland. A Lover's Discourse. New York: Farrar, Straus and Giroux, 2011.

Black, Jeremy and Anthony Green. Gods, Demons and Symbols of Ancient Mesopotamia. An Illustrated Dictionary. Austin and London, 2004.

Braginskaya, Nina. Why eros have wings? Issues of classical philology. Moskow: Nikeya, 2011, 53-94.

Chroust, Anton-Hermann. The Influence of Zoroastrian Teachings on Plato, Aristotle, and Greek Philosophy in General. New scholasticism, Vol.54 (No 3), 1980: 342-357.

Digby, Tom. Love and War. How Militarism Shapes Sexuality and Romance. Columbia: University Press. 2014.

Ivanova-Kazas, O. M. Zoological mythology. Sankt-Peterburg: Faculty of philology of SPbSU, 2004.

Lexicon Iconographicum Mythologiae Classicae (1986). Zürich und München: Artemis Verlag, III.1, Atherion — Eros.

Malakhov, Viktor. View on love, Ethics of communication. Kyiv: Lybid', 2006: 362-369.

Ruzhmon, Deni de. Art of love and art of war. Colege of sociology. Sankt-Peterburg: Nauka, 2004, 267-290.

Yarovoi, Andrey. From culture of war to war of cultures: social and cultural projects of agonality. Moscow, Berlin: Direkt-Media, 2017. 